\title{
ALVĪNE ANNA PĀVULE UN FIZIOLOGIJA LAIKA GAITĀ
}

\begin{abstract}
Alvīne Pāvule "Rokas un durvis":
Dažs labs neizpratnē raustīs plecus: nu ir gan atraduši par ko runāt, kāds gan sakars starp šìm divām lietām? Jā, mīlie draugi, sakars starp lietām ir visur un vienmēr. Manas durvis vēl visas ir klasiskā tipa ar rokturiem, lai gan tie ir dažādas formas un lieluma. Bet gandrīz visi, kas staigã caur mani, neredz manu durvju rokturus.

Pateicībā un ar lielu pietâti atveram šĩs durvis ar dažãdiem rokturiem un savā izpratnē aplūkojam dzīves telpu.

Alvīne Anna Pāvule dzimusi 1910. gada 2. jūnijā Slokas pagasta "Mežbeltēs". Ja ielūkojamies kartē, tad tuvā apkārtnē iezīmējas Slokas ezers, mājas "Mežlauki" un "Vizbulītes".

Pāvulu g̀imene: tēvs - Pēteris Pāvuls, māte Paulīne Pãvule - zemkopji; vinu bērni - meitas Amālija, Emīlija un Alvīne, dēli Jānis un Andrejs. Alvīne ġimenē mịli saukta par Kūmu, Kūmin̨u.

Terminu "fiziologija" 1542. gadā ieviesis Žans Fernels (Jean Fernel), lai ať̌kirtu cilvēka dzīves normālos fenomenus no patolog̀iskajiem (P. Dejours, 1990).
\end{abstract}

\section{SAKNES}

SLOKA - senākā Jūrmalas apdzīvotā vieta, kurai 1785. gadā pieškịirtas pilsētas tiesỉbas. 1877. gadā dzelzcẹa Rīga - Kẹemeri - Tukums izbūve būtiski ietekmēja Jūrmalas attīstību.

Var tikai minēt, vai interese meitenei par medicīnu rodas, iepazīstoties ar 1897. gadā vecajā drukā izdoto grāmatu, kuras pirmajā lapā ar spalvu ierakstîts - J. Pahwul. Tã ir 1873 lap-

\section{FIZIOLOGIJA PASAULĒ}

1889

Pirmais Starptautiskais fiziologu kongress.

1890

Oto Franks (Otto Frank) pierāda iestiepuma efektu izolêtā vardes sirdī. 1896

E. H. Stārlings (E. H. Starling) demonstrē onkotiskā spiediena nozīmi šḳidrumu sadalē kapilăros. 
pušu bieza un saucas "Jaunā dabas ārstēšanas metode...", kurā cita starpā teikts: "tã saucamā lielã asinsrite pa artêrijäm skäbekla asinis sadzen kapilāros un tad pa vēnām tumšās, oglekla bagātās asinis atkal tiek piegādātas sirdij".

\section{SKOLAS GAITAS}

Alvīne aizsāk 1919. gadā Slokas pilsētas sešklasīgajā pamatskolā, vēlāk, no 1925. līdz 1929. gadam, mācās Rīgas Jūrmalas pilsētas vidusskolā Dubultos; šeit veidojas nākamā personība.

Uz 1925. gada pavasara skolnieces fotogräfijas ar viṇas pašas roku rakstīts:

\section{(Aīda Niedra)}

Kas esmu, tã esmu, visa,

Mans skatiens ir atklāts un drošs,

Es vienmêr degu. Man nīstams

Viss remdens un sastingošs!

STUDIJAS LU Medicīnas fakultātē 1930.-1936.

Studijas A. Pāvule beidz ar atzīmi "loti sekmīgi".

\section{5/36}

Darbs "Ischias et spondylosis deformans" -2 . vieta studentu zinātnisko darbu sacensīibās.

1935

Vasaras prakse Stokholmā.

Studiju laikā voluntē pie prof.

J. Miḳelsona Iekškīgo slimību katedrā.

1936

Rīgas pilsētas 1. slimnīcā strādā laboratorijāa, vielmaiṇas un EKG kabinetā. Trīs mēnešus papildinās klīniskajā laboratorijā Londonā.
1897-1898

$\mathrm{R}$. Tigerstets ( $R$. Tigerstedt) "Lehrbuch der Physiologie des Menschen". 1. izd. 1898

R. Tigerstets un P. G. Bergmans

(R. Tigerstedt, P. G. Bergman) atklāj renīnu.

1910

A. Kosels (A. Kossel) - zināšanas par šūnu k̦īmiju (olbaltumiem).

1919

Ž. Borde (J. Bordet) - imunitātes pêttījumi.

1920

A. Kroga (A. Krogh) pētijumi par kapilāru regulācijas mehānismu.

1922

A. Hilla (A. Hill) pētijumi par siltuma produkciju musku|os; O. Meierhofs (O. Meyerhof) raksturo attiecỉbas starp skābek|a patērinu un pienskābi musku|os.

1924.

V. Einthovens (W. Einthoven) - EKG mehānisms.

1929

F. Hopkinss (F. Hopkins) - augšanu stimulējošie vitamīni.

\section{ASINSRITES FIZIOLOGGIJA}

1914

E. H. Stārlings (E. H. Starling) izolētā sirds-plaušu preparātã demonstrē, ka sistoles tilpums ir kambaru diastoles beigu tilpuma funkcija.

1918

A. Krogs (A. Krogh) norāda uz sakarïbu starp vaskularizāciju un skeleta musku|u metabolismu kontrakcijas laikā. 
Daugaviete - 1933. g. II sem. 24. coets; A. Brigaderes vârdi precīzi raksturo arī Alvīni:

Violeti zali zelta

Triju krāsu saskaṇota;

Staro Daugavietes zìme

Ka var māsa pazīt māsu.

...Violets stāv pirmā vietā

Sirds un ziedon's...

Zalš ir pilnvasaras paisums

Zelts dailgudrā rudenība.

\section{SAKNES UN PERSONĪBA}

1936. 14. sept. A. Pāvule iegūst ãrsta grādu. Diploms Nr. 151 "uzliek tā üpašniecei pienākumu sekot medicīnas zinātnes ieguvumiem, pēc labākās sirdsapziņas kalpot sirgstošam cilvēkam". To A. Pāvule nekad neaizmirst.

1936

Volontē Iekšķīgo slimību hospitālajā katedrā.

1937

Ārste Dzelzcȩ̣a slimnīcā.

Papildinās Stokholmā klīniskajā laboratorijā, veicot serologiskas un mikrokīmiskas analīzes.

1937-1943

Asistente LU Medicīnas fakultātes Fiziologijas un bioḳīmijas katedrā.

\section{4-1945}

Laboratorijas vadītāja Aleksandra Augstumu psihiatriskajā slimnīcā.

Savā autobiogrāfijā Alvīne Pāvule raksta: "1944. gadā nav neviena mācību spēka, telpas izdemolētas, dala aparatūras izvesta, dala sabojāta, bet decembrī fakultātē varēja uzsākt mācības".
1920

T. Luiss (Th. Lewis), K. J. Vigerss

(C. J. Wiggers) - pirmie apraksti par vienlaicīgām elektriskām un mehāniskām norisēm sirdsdarbỉbas ciklā.

\section{Grāmatas fiziologijāa un asinsrites raksturojums šajā laikā:}

\section{9}

R. Tigerstedt. Lehrbuch der Physiologie des Menschen. - Leipzig. 1. dạa 627 Ipp. 13. noda|a: lekšējā sekrēta ieplüšana asinsritē ... orgāmu veidotie produkti ar asinīm vai limfu aiziet un savelk gludos muskulus un ievērojami celas tomuss... Šãdas vielas ir suprarenīns vai adrenalīns.

1920

P. Schultz. Physiologie des Menschen und der Säugetiere. - Berlin; 308 lpp.

[Asinsvadu musku|u vazomotoriskie nervi, vazokonstriktori,vazodilatatori (chorda tympani et nn. erigentes); centrs iegarenās smadzenēs un tã tonuss.];

J. Thorton. Physiology. - London; 464 lpp. [...asinsplūsmas perifērā pretestỉba ir atkarīga no vazomotoriskã centra; artērijas dilatējas, ja centrs kavēts.]

1923

R. Rosemann. Lerbuch der Physiologie des Menschen mit besonderer Berücksichtigung der praktischen Medizin. - Berlin; Wien. 970 lpp. Demonstrē Franka-Petera atspermanometru asinsspiediena mērī̌anai. 1931

F. Barth. Physiologie in Frage und Antwort. - Heidelberg;198 lpp.

Raksturo pulsa līkni ar sfigmogrammas pierakstu; 


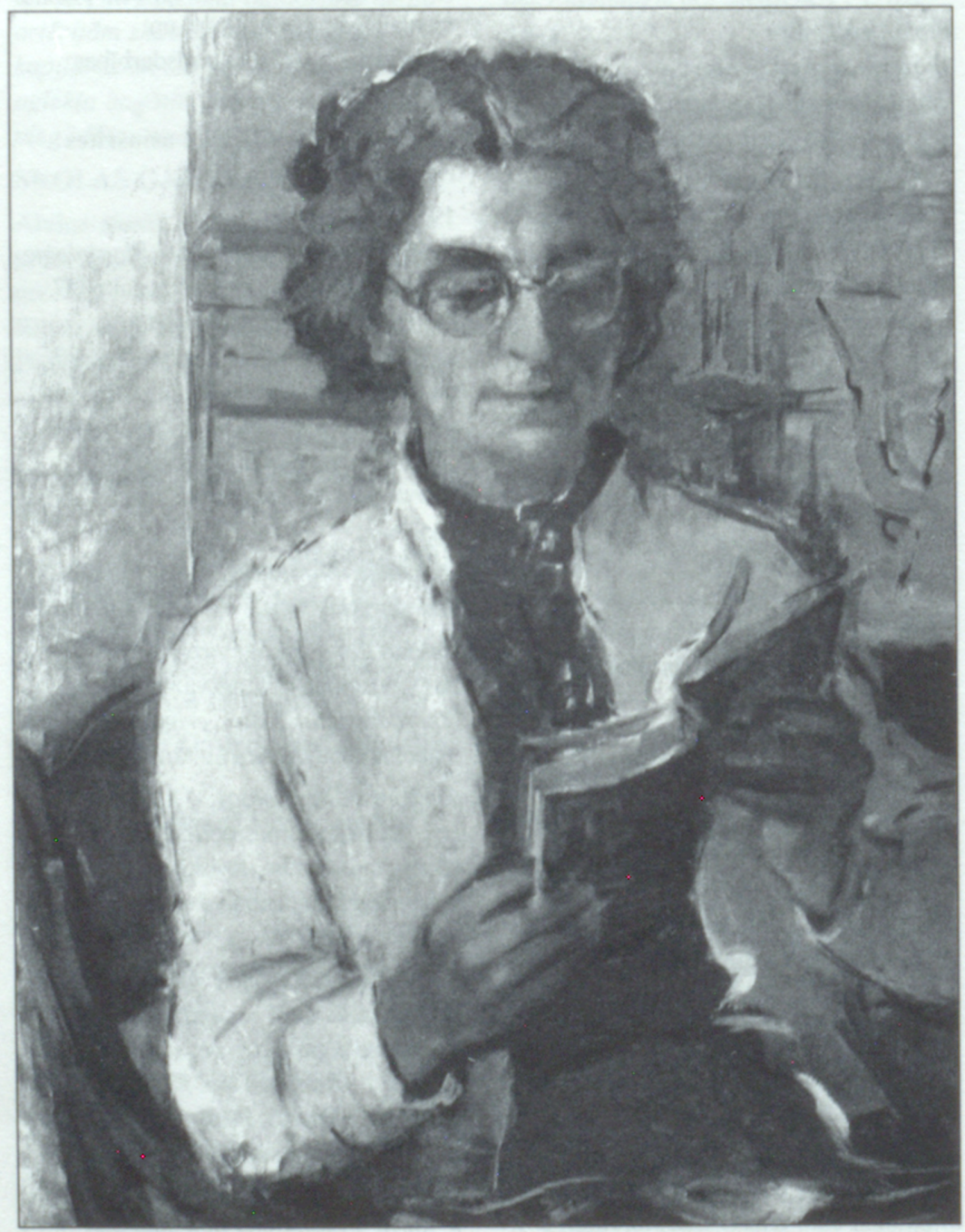

Alvīnes Pāvules portrets. Māksliniece A. Be|cova, ella, 20.gs. 60. gadi 


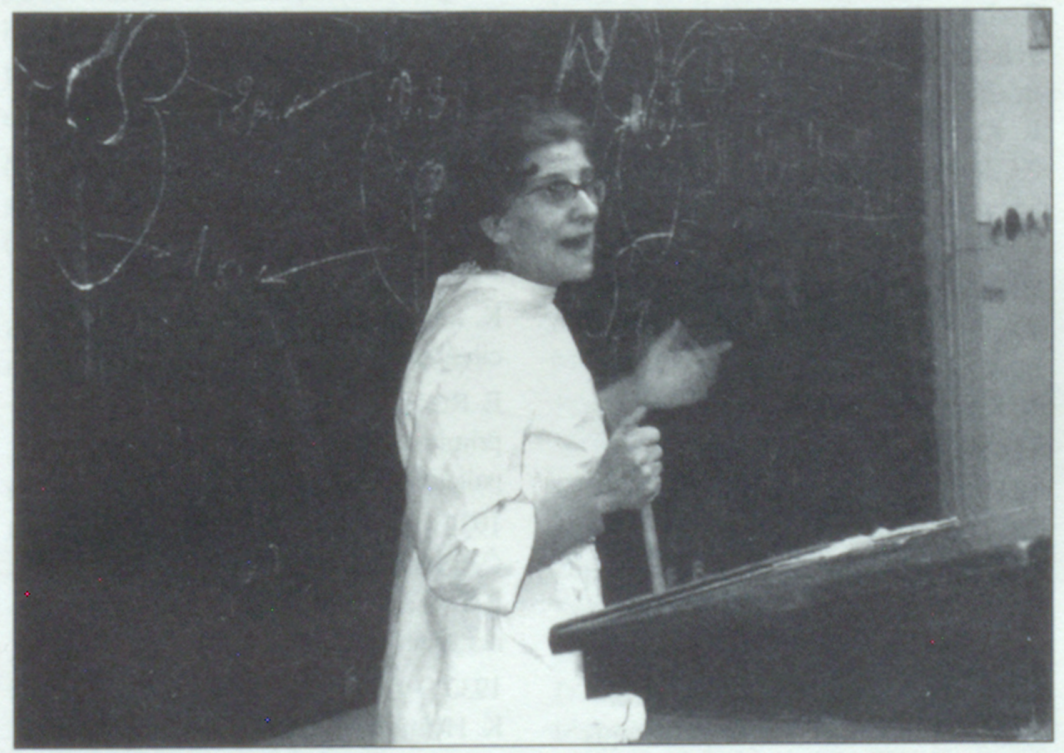

Alvīne Pāvule lasa lekciju studentiem. 1973 
1945

A. Pãvule sanem meda|ju par labu darbu.

1944/45

LVU Bioḳimijas katedras vadītāja

(līdz prof. A. Šmita atbraukšanai).

Pãvule - Krimbergs - Vegers Miķelsons

1920-1940

ROBERTS KRIMBERGS (Maskavas universitātes skola) vada Fiziologijas institūtu ar fiziologijas k̂̄miju.

R. Krimbergs dāvina A. Pāvulei savu XI Starptautiskā fiziologu kongresa, kas notika Edinburgā 1923. gadā no 23. līdz 27. jūlijam, delegāta reg̉istrācijas karti Nr. 389.

1941

Pāvules redakcijā izdotas

R. Krimberga lekcijas fiziolog̉iskajā ķīmijā.

1941-1944

PETERIS VEGERS (absolvējis LU) vada divas katedras - Fiziologijas katedru un Fiziologiskās ķīmijas katedru.

1944-1946

JĀNIS MiḳElsons (Tērbatas Universitātes skola) vada Hospitālās terapijas katedru un Fiziologijas katedru.

Pãvule - Zubkovs (Maskavas universitātes skola) 1946-1948

A. Pāvule uzsāk nosacījumu refleksu izstrādi akūtā eksperimentā ar suñiem. 1946. gadā A. Pāvule piedalās LVU Medicīnas fakultātes 1. un 1947.gadā 2. zinātniskajā sesijā; piedalās arī Vissavienỉbas fiziologu kongresā Maskavā. 1946./47. g. kopā ar I. Mežuli tulko A. Zubkova lekcijas "Cilvēka fiziologiijas kurss".
R. Hoober; 609 lpp.

Demonstrē Riva-Roči sfigmomanometru. Apraksta vietējās asinsvadu reakcijas un tonusu; funkcionālu asinsvadu paplašināšanos darbojošos orgānos un muskulos.

1941

E. Abderhalden. Lehrbuch der Physiologie. - Berlin; 392 lpp.

[Vazokonstriktorajam centram ir raksturīgs automātisms. Koronāro artēriju simpātiskās šķiedras ietekmē vazodilatatoru funkciju, saglabājot asinsvados parasimpātisku sašaurinošu darbību.]

\section{FIZIOLOGIJA PASAULE}

1930

K. Landక̌teiners ( $K$. Landsteiner) atklāj cilvēka asins grupas;

E. Ruska (E. Ruska) izgudro pirmo primitīvo elektronu mikroskopu, kas palielina 400 reižu.

1932

Č. Šeringtons ( $\mathrm{Ch}$. Sherrington) un

E. D. Edriens (E. D. Adrian) apraksta neironu funkcijas.

1933

K. Heimanss (C. Heymans) atklāj ķīmijreceptorus aortas lokā, karotīdes sinusā;

T. Morgans (Th. Morgan) pierāda hromosomu nozīmi iedzimtỉbā.

1936

H. Deils (H. Dale) un O. Lẽvi

(O. Loewi) pierāda nervu impulsu pārvadi ar ķīmisku ag̀entu starpniecỉbu.

1937. - M. Alens (M. Alan) un

F. H. Smirks (F. H. Smirk) pierāda asinsspiediena paaugstināšanos un sirdsdarbỉbas paātrināŠanos cilvēkam skeleta muskulu aferento nervu ietekmē. 
[Sāpīgu kairinātāju ietekme. Rodas jautājums, kas ir sāpīgā kairinājuma radītās vazokonstrikcijas tiešais iemesls? Asinsvadu sašaurināšanos izraisa adrenalīns, vazopresīns, angiotonīns. Šo vielu atklāja nesen un nav vēl zinâms, vai tā ir arī vesela cilvēka asinīs.] Mūsu dienās tiek uzsvērta renīna-angiotenzīna sistēmas nozīme asinsvadu sašaurināšanā un asinsspiediena regulācijā.

Pãvule - Daṇilovs (Zieme|kaukāza universitătes skola) 1948-1958

Medicīnā pēc 1946.-1949. g. tiek pārspīlēta Pavlova mācības interpretācija (I. Lazovskis, A. Vĩksna, 1991).

1948

A. Pāvule. Asinsvadu kondicionālie refleksi (zinātniskais raksts rokrakstā). 1949

A. Pāvule. Elpošanas izmaiñas, izstrādājot sirds-asinsvadu nosacījuma refleksus (LU Medicīnas fakultătes III zinātniskā sesija).

1950

A. Pāvule aizstāv disertāciju "Sirdsasinsvadu nosacỉjuma refleksi uz sāpīgiem kairinātājiem" medicīnas zinātṇu kandidāta grāda iegūšanai. Darbā pētīti 29 suṇi (traheotomija, a. carotis un a. femoralis kanilēsana, atkailināts $n$. femoralis, nosacījuma refleksu izstrāde), kã arī 10 cilvēku (12 mēg̀inājumu), kuriem $a$. radialis sfigmogrammas registrācija kombinēta ar metronomu un sāpīgu kairinātāju, un 5 cilvēki, kam, esot stomatologiijas krēslā, sfigmogramma kombinēta ar elektriskās urbjmašinas troksni un zobu sâpēm.
1938

K. Heimanss (C. Heymans) noskaidro karotīes sinusa un aortas mehānisma nozīmi elpošanas regulācijā.

1940

A. Kurnăns (A. Cournand) izmanto savu sirds priekškambara asinuu paraugu un Fika principu, lai noteiktu sirds minūtes tilpumu cilvēkam.

1945. g. LVU pirmā zinātniskā sesija: medicīnas sekcijā piedalās 365 klausîtāji; tā norisinās Raina bulv.19, 5. klausîtavã.

Lektore A. Pāvule: "Ca un K jomu ietekme uz sirds muskulu kontrakciju" tā iedrukāts programmā. Bet turpat sesijas piezīmes glabā, domājams, ar prof. K. Rudziša roku rakstîtu četrrindi, asistējot prof. A. Šmitam:

Pârāk daudz zelta

Mẽness ieleja

Vēstules par cerību

Sniega meita.

\section{Zinātnieki pasaulē par kalcija un kālija nozīmi asinsritē}

20. gs. 60. gados

D. Nobls (D. Noble), raksturojot elektrisko aktivitāti sirds muskulī, norāda uz kālija plūsmu Purkiṇe šḳiedrās.

1972

A. Fabjato (A. Fabiato) konstatē miokardā sarkomērus, kas jutīgi pret kalciju, un kalcija izdalīsanos no sarkoplazmātiskā tîkla.

\section{FIZIOLOGIJA PASAULĒ}

1940

Dž. Bīdls ( $G$. W. Beadle), E. Teitems

(Ed Tatum), B. Efrusi (B. Ephrussi)

norāda uz ġenētikas saistỉbu ar bioķīmiju. 
Secinājumi: cilvēks uz sāpīgu kairinājumu reaġē ar asinsspiediena paaugstināšanos un pazemināšanos; mainās arī elpošanas ritms un dziljums; nosacījuma refleksi ârsta kabinetā izstrādājas âttrāk nekā laboratorijas apstāḳıs.

\section{ALVĪNE PĀVULE - RMI}

1950

LVU Rektors prof. J. Jurgens aizrāda, ka jāseko padomju literatūrai.

1951

RMI direktors E. Burtnieks, partijas sekretârs A. Čukalovskis: zinātniskā darbā A. Pāvule izvēlas pētīt cilvēka nosacījuma refleksus, lasa un referē Pavlova un vina skolas darbus; no 1949. strādā prof. N. Danilova vadībā, lasa lekciju kursu latviešu valodā; sarakstījusi latviešu valodā praktisko darbu aprakstus fiziologijāā.

1953. gada 16. oktobrī A. Pāvuli ievēl par docenti normālajā fiziologijā.

Obligātie Vissavienības kvalifikācijas kursi Maskavã un Leningradā (1952, 1967, 1970).

Direktora Burtnieka atzinums 1955. gadā: kvalificēts speciālists.

A. Pāvule ir oponente A. Dālmanes (1955), J. Šustera (1958), E. Melka (1963), J. Baltkāja (1965) u.c. disertācijầm. J. Krēmers 1954. gadā pateicas par lielo palīdzību kandidāta disertācijas darba veikšanā.

1958. 12. decembrī A. Pãvuli ievēl par Normãlãs fiziologijas katedras vadītāju.

1959. g. A. Pãvulei ir 17 zinātniskās publikãcijas. Zinātniskais darbs mainîjās vairākkārt sakarā ar pâr-
1943

T. Averijs (Th. Avery), K. Maklauds (C. McLeod), M. Makārtijs (M. McCarthy) demonstrē genētisko pārmantotíbu;

H. Dams (H. Dam) atklāj K vitamīnu, bet E. A. Doizijs (Ed. A. Doisy) izpēta K vitamīna k̦īmisko dabu.

1950

E. Kendals (Ed. C. Kendall),

T. Reihšteins (T. Reichstein), F. Henčs (Ph. Hench) apraksta virsnieru garozas hormonus, to struktūru un biologiskos efektus.

1953

H. Krebss (H. A. Krebs) izpēta trikarbonskābes ciklu;

F. Lipmans (F. Lipmann) pierāda koenzīma A starpnieka lomu metabolismā. 1955

A. Teorels (A. H. Theorell) izpēta oksidācijas enzīmu dabu un darbību.

\section{ASINSRITES FIZIOLOĢIJA}

1950

K. Heimanss (C. Heymans) pierāda, ka baroreceptori spēj adaptēties.

1954

S. Sarnovs (S. J. Sarnoff) norāda, ka inotropiskas vielas modulē sirds priekšslodzi, bet 1966. gadā ultrastruktūras pētijumos atklāj priekšslodzes ietekmi uz sarkomēra garumu.

1955

A. C. Gitons (A. C. Guyton) attīsta vienlaicīgu sirds funkcijas grafisku analīzi, pildoties priekškambariem: uz Y ass minūtes tilpums, uz $\mathrm{X}$ ass - vidējais spiediens. 
maiṇām sabiedriskajā iekārtā, kā arī mainoties katedras vadītājiem.

1959. un 1963. g. A. Pāvulei izteikta LPSR Veselības aizsardzības ministrijas pateicība, bet 1973. gadā viṇa klūst par Veselības aizsardzības teicamnieci.

1969. g. 20. jūnijā A. Pāvule Tartu sekmīgi aizstãv medicīnas doktora disertāciju "Apzarṇa asinsvadi kā refleksogēnā zona". Disertācija sarakstīta krievu valodā, tai ir 504 lpp., pētīti 123 dzīvnieki, vērēs 1345 literatūras avoti, t.sk. 543 krievu valodā. Trīs pētījumu sērijas: 1) apzarña presorais efekts; 2) asinsvadu tonusa, sirdsdarbības un arteriālā spiediena izmaiñas akūtas da|ējas zarnu išemizẫijas gadījumã; 3) daži sirds un asinsvadu funkcijas rādītāji suṇiem modelī ar hroniskiem traucējumiem apzarņa asinsritē.

Akadēmiķa J. Babska atzinums: Pēc faktu materiāla un rezultātiem, kas vērtīgi virknei medicīnas nozaru, darbs atbilst visām doktora disertācijas prasībām. Arī akadēmiḳis

A. Krauklis dod pozitīvu vērtējumu.

Fiziologijas mãcību grāmatas Latvijā 1955

K. Bikovs (red.). Mācību grāmata fiziolog̀ijā (kr. val.), 880 lpp.

1966

J. Babskis (red.) Cilvēka fiziologija (kr. val.), 656 lpp.

1963
A. Pâvule. Daži fizioloğijas pamatjēdzieni. - Rīga. - 38 lpp. 1972

Cilvēka fiziologija. - Rīga: Zvaigzne. 345 lpp., 128 zìm., 29 tab.
1956
A. Kurnāns (A. Cournand),
V. Forsmanis (W. Forssmann),
D. Ričardss (D. Richards) izstrādāja sirds katetrizāciju, pētija patologiskas părmainas sirdī.

1957

D. Bovets (D. Bovet) atklāja sintētiskus savienojumus (kavētājus), kas īpaši darbojas asinsvadu sistēmā un skeleta muskujos.

1950-1960

Pētijumi par Franka-Stārlinga mehānismu un sirds kontraktilitātes reflektoro regulāciju; R. J. Rašmera (R. J. Rushmer) pētijumi par sirdsdarbỉbu hroniskā eksperimentã ar suṇiem un sirdsdarbības izmainăm dažādos fiziologiskajos apstāklos.

1956

J. P. Henrijs (J. P. Henry), O. H. Gauers $(O . H$. Gauer $)$, Dž. L. Rīvss

(J. L. Reevs) norāda, ka ātriju receptori ietekmẽ urīna plūsmu.

1981

De Bolds (A. F. De Bold) atklāj nātrija urētiskã peptīda izdalīsanos no priekškambaru miocîtiem.

\section{FIZIOLOGIJA PASAULĒ}

1971

E. Saterlends (E. Sutherland) apraksta hormonu darbïbas mehānismu.

1974
A. Klods (A. Claude), K. R. de Divs (Ch. R. de Divve), Dž. Palādi
(G. Palade) - šūnas strukturālā un funkcionālā organizăcija.

1972

A. Pāvule grāmatā "Cilvēka fiziologija"
asinsvadu gludajā muskulatūrā apraksta 
Alvīnes Pāvules asprātīgie bumbiṇrakstu|a uzmetumi vēstulēs

1969. oktobrī no Rīgas: Es esmu vēl viena no dzivi palikušajiem mohikāniem.

1970.maijā no Rīgas: Jūtos tāpat kã visi studenti pavasarī - koša saule un pirmais zalums.

1970. decembrī no Rīgas (par slāviem): Neizprotamas lietas: vareni spēkavīri literatūrā, mūzikā, izpildītâji dažādos mākslas veidos utt., bet raksturs tāds pats kā müsu pašreizējie laika apstāklii: 24 st. laikā pārdzìvojam turpat vai visus četrus gadalaikus.

1973. aprîlī no Leneningradas:

Salìdzinot ar Gandiju, ēdu daudz, bet salīdzinot ar mājas apstākliem - maz. Vai svara krišanās lìdzsvarosies ar gara augšanu, vēl grūti sacīt.

1975. 19. martā pēdējā vēstulē no Rīgas: Šodien pat dzirdēju ḳivîti un nobrīnījos, ka vina tik pelèkà kūlā brēc savu brēcamo. Parasti es vinas dzirdu tikai, kad Lielupes krasti jau zalum zali.

\section{SAKNES UN NĀKOTNE}

Jaunķemeri. Slokas ezers.

Gulbji ezerā. Klaigā.

Drì vini projām dosies. Aizlidos laikā.

Viens vienmēr nosebosies.

(I. Ziedonis, 1992) alfa un beta adrenoreceptorus, kas reaǵé uz kateholamīniem, kã arī dažādus acetilholīna receptorus.

1980

R. F. Ferhgots ( $R$. F. Furchgott) demonstrē, ka kapilâru endotēlijs modulē apkārtējo asinsvadu gludo miocìtu kontraktilo stāvokli.

1994

A. Gilmans (A. Gilman), M. Rodbels (M. Rodbell) atklāj G olbaltumu. 1998

R. Ferhgots (R. Furchgott), L. Ignaro (L. Ignarro), F. Mira (F. Murad) apraksta slāpek|a oksīdu kā asinsrites sistēmas signālmolekulu.

\section{Kardiovaskulārās fiziologijas vēsture}

liecina par cilvēka prāta spējām atklāt dabas noslēpumus un izmantot šiss zināšanas cilvēka dz̄ives uzlabošanai. 20. gs. tā lieliem soliem apguva audu, orgānu un sistēmu līmeñus kardiovaskulārajā integrācijā. Šã gadsimta pēdējā ceturksnī uzsvērti kardiovaskulāro funkciju molekulārie un šūnu mehānismi. Jaunās tūkstošgades sākumā notiek svarīgs pagrieziens uz jaunu, fundamentālu pieeju pētịjumiem.

Multidisciplināra pieeja atbrīvos kardiovaskulāro zinātni no disciplīnā bāzētiem ierobežojumiem un paradigmầm. 


\section{Treji loki savijuši kopā visu Alvīnes Annas Pāvules padarīto un citiem doto}

- Tas ir nesavtīgs, rūpīgs, pamatīgs un precīzs darbs, arvien rosinošs un tālākvadošs.

- Tas ir pienākums pret sịko ikdienu un pamatdarbu, pret sev tuviem un tālāk stāvošiem cilvēkiem, pret dabu un sabiedrību.

- Tas ir atvērtas, dāsnas sirds loks, kurā sava vieta ir visam dzīvajam: cilvēkiem, dzīvniekiem un dabai.

\section{Vēres}

A. Pāvules gimenes arhīvs.

$A M L$ personāla arhīvs.

Lazovskis I., Vīksna A. Medicĩnas zinātne Latvijā laika gaitā // Latvijas Zinātṇu Akadēmijas Vēstis. - 1991. - Nr. 6. - 51.-55. Ipp.

Dejours $P$. Physiology in France in the late $18^{\text {th }}$ century and during the $19^{\text {th }}$ century: The roots of modern physiology. - Oulu (Finland), 1990. - 9.-20. Pp.

The Nobel Foundation. - 1999.

Grauger H. J. Cardiovascular physiology in twentieth century: great strides and missed opportunities// American Journal of Physiology. - 1998. - Dec.

Looking back on the Millennium in Medicine // New England Journal of Medicine. 2000. - January, 6.

\section{Alvine Anna Pavule and Physiology Along Years (Summary)}

By Liga Aberberga-Augškalne

Alvine Anna Pavule born 2 June 1910, in Sloka in the family of farmers, graduated very successfully from Jurmala Secondary School and Medical Faculty of Latvia University in 1936. All of her life was closely tied with cardiovascular physiology. She was an excellent, intelligent teacher for the students and physiologists, permanent chief of the Department of Physiology till 1975. Her scientific interests were in the hard and precise field of the experimental physiology where the practical outcome was related to humans and she defended two dissertations with great success. A. Pavule edited the first book in human physiology in Latvian in 1972 and had many scientific articles and reviews. Her life was selfless, accurate and creative labour, obligation to minor things as well as to principle, to close people and society at large, to animals and nature. She had an open and giving heart for all living things.

The history of the cardiovascular physiology provides testimony to the ability of the human mind to reveal nature's secrets and to use this knowledge to improve the human condition. Great strides were made in the $20^{\text {th }}$ century to the tissue, 
organ and system levels of cardiovascular integration. In the last quarter of this century, the emphasis has been on molecular and cellular bases of cardiovascular functions. At the new millennium, there are important signs pointing the fundamental approach to cardiovascular research. A renewed emphasis on the multidisciplinary approach will liberate cardiovascular science from the confinements of the discipline - based paradigm.

Lĩga Aberberga Augškalne, Dr. habil. med, prof.

RSU Normālās fiziolog̉ijas katedras vadītāja

Dzirciema iela 16, Rīga, LV-1007

Latvija

E-mail: aberberg@oic.lv 